\title{
PDGFRA Gene Mutation Negative
}

National Cancer Institute

\section{Source}

National Cancer Institute. PDGFRA Gene Mutation Negative. NCI Thesaurus. Code C138193.

A genetic finding indicating that PDGFRA gene mutations have not been detected in a sample. 